\title{
ERYTHROPOIETIN AND CARDIOVASCULAR SYSTEM
}

\author{
ERITROPOETIN VE KARDIYOVASKÜLER SISTEM
}

Aysel GÜVEN BAĞLA, Meltem IÇKiN

\begin{abstract}
Çanakkale Onsekiz Mart Üniversitesi, Tıp Fakültesi, Histoloji Ve Embriyoloji Ad. Çanakkale

Yazışma Adresi:

Aysel GÜVEN BAĞLA

Çanakkale Onsekiz Mart Üniversitesi, Tıp

Fakültesi, Histoloji Ve Embriyoloji

Ad.Terzioğlu Yerleşkesi. Çanakkale

Çanakkale - Türkiye

E posta drayselguven@yahoo.com
\end{abstract}

Kabul Tarihi: 26 Kasım 2012
Balıkesir Sağlık Bilimleri Dergisi

ISSN: 2146-9601

e-ISSN: $2147-2238$ bsbd@balikesir.edu.tr www.bau-sbdergisi.com

\section{ÖZET}

Eritropoetin (EPO), sağlıklı bireylerde kemik iliğinde normal eritrosit üretimi için gerekli olan bir glikoprotein hormondur. Hipoksik koşullar altında eritropoezi indükler. Renal peritübüler hücrelerden ve karaciğer, dalak, akciğer, beyin, kemik iliği, üreme organları gibi farklı ekstrarenal dokulardan salınır. EPO ile reseptörünün (EPO-R) etkileşimi, eritroid progenitör hücrelerin programlanmış hücre ölümünü (apopitozis) azaltır ve bu hücrelerin kemik iliğinde farklılaşmasını teşvik eder. Klinik olarak, rHuEPO (rekombinant insan EPO) kronik böbrek yetmezliği sonucu gelişen EPO eksikliğine bağlı anemi tedavisinde 1980'lerin sonlarından beri kullanılmaktadır. EPO-R, eritroid progenitor hücrelerin yanı sıra, nöronlar, endotel hücreleri, vasküler düz kas hücreleri ve kalp kası hücreleri gibi çeşitli hücre gruplarında da eksprese edilir. EPO nun kalp, böbrekler, retina, karaciğer, akciğer, bağırsaklar ve beyinde hipoksi ve iskemireperfüzyon hasarına karşı sitoprotektif etkiye sahip olduğu gösterilmiştir. EPO'nun temel sitoprotektif etkisinin iskemik/hipoksik dokuda apopitozisi inhibe etmek olduğu öne sürülmüştür. Apopitozisin inhibisyonu yanı sıra, EPO doğrudan ya da dolaylı olarak hücreleri koruyan pek çok farklı etki de göstermektedir. Bu nedenle EPO genel doku koruyucu bir sitokin olarak değerlendirilmelidir.

Anahtar Kelimeler: Eritropoetin, kök hücre, kardiyovasküler sistem

\section{SUMMARY}

Erythropoietin (EPO) is a glycoprotein hormone which is essential for normal erythrocyte production in bone marrow in healthy subjects. It induces erythropoiesis under hypoxic conditions. It is released from renal peritubular cells and various extrarenal tissues like liver, spleen, brain, lungs, bone marrow, reproductive organs. Interaction of EPO with its receptor (EPO-R) decreases programmed death (apoptosis) of erythroid progenitor cells and promotes their differentiation in bone marrow. Clinically, rHuEPO (recombinant human EPO) has been used since the late 1980s in patients with anaemia due to EPO deficiency as a consequence of chronic renal failure. In addition to erythroid progenitor cells, a varied group of cells including neurons, endothelial cells, vascular smooth muscle cells, and cardiac myocytes express EPO-R. It has been shown that Epo has cytoprotective properties against ischemia reperfusion damage and hypoxia in the brain, heart, kidneys, retina, liver, lungs, and intestines. It was suggested that inhibition of apoptosis in ischemic/hypoxic tissue is the major cytoprotective effect of EPO. In addition to inhibition of apoptosis, EPO exhibits many other actions that serve to protect cells either directly or indirectly. EPO should therefore be regarded also as a general tissueprotective cytokine.

Keywords: Erythropoietin, stem cell, cardiovascular system

\section{Introduction}

EPO is primarily expressed in the liver in fetal life. After birth, the kidneys become the main site of production ${ }^{1}$ which occurs in response to hypoxia. ${ }^{2}$ EPO gene expression is oxygen-dependent and is primarly regulated by hypoxia-inducible transcription factors (HIF 1, 2 and 3) as well as nuclear factor kappa B (NF-kB). ${ }^{3-6}$ The expression of EPO mRNA reaches its maximum level at 4-8 $\mathrm{h}$ after exposure to hypoxia, which is the time needed for HIF activation. ${ }^{7}$ EPO production in the kidney is induced by the factors that create tissue hypoxia or decreased renal blood flow. ${ }^{8}$ Although possible EPO production in renal tubular cells was reported 
previously ${ }^{9,10}$ a more recent study has shown that fibroblast-like cells in the corticomedullary interstitium of the kidney synthesize EPO, while tubular cells do not. ${ }^{8}$

Proliferative effect of EPO on several progenitor cells including erythroid progenitor cells, ${ }^{11-13}$ endothelial progenitor cells (EPC), ${ }^{14,15}$ cardiomyogenic stem cells ${ }^{37}$ has been reported.

EPO is known to act specifically on haematopoietical cells, however recent evidence demonstrated several non-haematopoietical effects. Initially, research focussed on the direct effect on haematopoiesis and correction of anaemia. Accumulating evidence suggest that EPO is a general tissue protector affecting many other systems besides hemopoietic sysytem. ${ }^{16-19}$ EPO exerts protective effects against tissue ischemia via its interaction with its receptor, EPO-R. ${ }^{20-31}$

Cardioprotective effect of EPO has become a current issue after detection of EPO-R expression on cardiomyocytes. ${ }^{32}$ EPO inhibits apoptosis and limits infarct size during ischemia and reperfusion through activation of various intracellular signaling pathways, especially PI3K-Akt pathway. The cardioprotective effect of EPO is independent of its hematopoietic effects. ${ }^{28}$ Similar antiapoptotic and cardioprotective effects of EPO independent of its hematopoietic effects have been shown with carbamylated EPO, a nonerythropoietic derivative of EPO, and with HBSP (helix B-surface peptide), a peptide mimicking the $3 \mathrm{D}$ structure of EPO. ${ }^{33}, 34$ Erythropoetic and cardioprotective effects of EPO led researches start to investigate use of EPO in cardiovascular medicine.

Anti-inflammatory, anti-oxidative, and angiogenic effects of EPO have also been reported. ${ }^{35}$ In this minireview, we discussed the role of EPO in cardiovascular system development and its cytoprotective effect on cardiomyocytes in course of myocardial infarction in the light of in vitro and in vivo studies.

\section{EPO in cardiovascular system development:}

The development of cardiac cells from embryonic stem cells is regulated by erythropoietin and other several growth factors such as TGF- $\beta$, IGF, insulin and FGF. The very high levels of EPO/EPO-R expression in many tissues during embryonic and fetal development decrease rapidly after birth to the generally low levels found in the adult. ${ }^{36} \mathrm{Wu}$ et al. ${ }^{37}$ demonstrated a novel function of EPO and $E P O-R$ in embryonic heart development. They reported that both EPO-/- and EPO-R-/- mice suffer from ventricular hypoplasia together with defects in the intraventricular septum and suggested that these cardiac abnormalities are due to a reduction in cell proliferation which appears specific to the heart. They detected EPO-R expression in all layers of the heart except myocardium. They suggested that EPO triggers cardiomyocyte proliferation probably in a non-cell-autonomous manner, EPO/EPO-R may provide mitogenic signals to cardiomyocytes and these mitogenic signals then promote cell proliferation. Their results explain a novel role of erythropoietin in cardiac morphogenesis and suggest a combination of anemia and cardiac failure as the cause of embryonic lethality in the EPO-/- and EPO-R-/- animals. ${ }^{37}$ Cardioprotective effect of recombinant human EPO (rHuEPO) against the development of left ventricular hypertrophy and premature death induced by chronic left ventricular systolic pressure overload due to transverse aortic constriction in mice was reported by Wang et al. ${ }^{38}$

An alternative explanation for the coronary defects is the direct effect of EPO signaling on endothelial cells. EPO has been shown to act as a mitogen factor for cultured endothelial cells and to enhance angiogenesis in the chorioallantoic membrane. ${ }^{39}$ Endothelial cell progenitor regulation is complex and may be mediated via direct cell-cell interactions, extracellular matrix molecules, as well as by soluble factors, erythropoietin and other several growth factors. These regulatory components interact and modulate the effects of one another and are themselves further regulated by physiological stimuli. ${ }^{40}$

During embryo development, immature primitive erythroblasts begin to enter the bloodstream with the onset of cardiac contractions. ${ }^{11} \mathrm{Ji}$ et al. $^{41}$ hypothesized that the timing of onset of heartbeat and erythroid cell migration are tightly coordinated. With the onset of cardiac contractions, scattered erythroblasts were observed within the head region and aorta of the embryo. ${ }^{11,41}$ EPO may be possibly creating a stimulus for the onset of cardiomyocyte contractions. 
Consequently, the presence of EPO during embryonic heart development seems to be necessary for healthy growth. Several studies, both in vitro and in vivo, are now in progress to investigate use of EPO in cardiovascular diseases during fetal life.

The effect of EPO on cardiomyocytes and myocardial infarction (in in vitro and in vivo studies):

Progenitor Cells and EPO:

EPO is a principal regulator that promotes proliferation and terminal differentiation of erythroid progenitor cells. EPO and stem cell factor are essential factors in the control or survival, expansion and differentiation of erythroid progenitor cells. In vitro and in vivo studies suggested that EPO may have a role in expansion of the progenitor pool, with or without other growth factors. ${ }^{11,}{ }^{12}$ Exogenous erythropoietin abrogates apoptosis of immature primitive erythroid cells cultured in vitro. ${ }^{13}$

EPO promotes endothelial progenitor cells (EPC) proliferative and adhesive properties. Stimulation of cultured endothelial cells with rHuEPO resulted in cell proliferation and differentiation into vascular structures. ${ }^{15}$ George et al. ${ }^{14}$ reported that EPC proliferative effect of EPO is dose dependent, it was evident at low doses such as $1 \mathrm{U} / \mathrm{ml}$ and lost at higher doses such as $25 \mathrm{U} / \mathrm{ml}$. Moreover, addition of EPO, dose dependently increased EPC adhesion to fibronectin, cultured endothelial cells and cardiomyocytes. These effects may promise a new therapeutic strategy in congestive heart failure patients to achieve EPC response induced by EPO. ${ }^{14}$

Stem cells and EPO:

The mitogenic effect of rHuEPO on primary cultures of neonatal rat cardiac myocytes was reported by Wald et al. ${ }^{42}$ rHuEPO triggered a dose-dependent increase in myocyte proliferation. 0,5 $\mathrm{U} / \mathrm{ml}$ EPO revealed maximum effect over optimally grown control culture 1 day after addition and it was inhibited with anti-rHuEpo. rHuEPO mediated mitogenic action on cardiomyocytes involves the activation of the same enzymatic pathways that have been described by other cytokines in different tissues. $^{42}$ Calvillo et al. suggested that erythropoietin increased human embryonic stem cell derived cardiomyocyte survival after injection into the infarcted heart. EPO has been shown to stimulate mitosis and signaling in endothelial cells, cardiomyoblasts, and cardiomyocytes maintained in vitro ${ }^{23}$.

In animal models Kessinger et al. demonstrated that use of EPO alone had a significant stimulatory role on collection of stem cells. ${ }^{12}$ rHuEPO therapy after stem cell transplantation is safe and well-tolerated. Four randomized studies show a decrease in transfusion requirement when rHuEPO is given early after allogeneic stem cell transplant although the magnitude of this benefit was small. ${ }^{43}$

Antonitsis et al. showed that transplanted human mesenchymal stem cells (MSCs) engraft at high numbers in infarcted heart and lead to functional benefit by increasing neovascularization and improving regional contractility. ${ }^{44}$ Strategies can be implemented to enhance myocyte and vascular growth promoting partial restoration of the infarct. ${ }^{45}$

Efficient differentiation of stem cells may not be sufficient for translating stem cell based heart therapies to the clinical setting. Considering the limited regenerative capacity of the heart muscle, renewable sources of cardiomyocytes are being searched. Many details about the exact signals directing the differentiation of ESCs to heart cells are still unclear. ${ }^{46}$

Cardiomyocytes and EPO:

EPO protects cardiomyocytes from apoptosis in vitro and in vivo. ${ }^{28,34} \mathrm{EPO}$, produced in response to hypoxia through HIF activation, binds to its receptor and activates intracellular survival signalling pathways, promoting not only red cell proliferation, but also progenitor cell mobilization, vasodilator, insulin-sensitizing, antithrombotic, antiapoptotic, and anti-inflammatory actions. ${ }^{32}$

Parsa et al. ${ }^{28}$ has shown that pretreatment of H9c2 cells (The myoblast cell line derived from embryonic rat heart) with EPO before exposure to $200 \mu \mathrm{M}$ $\mathrm{H}_{2} \mathrm{O}_{2}$ for 22 hours protects cells from apoptosis. They reported that this protection appears to be due to inhibition of apoptosis; after exposure to $\mathrm{H}_{2} \mathrm{O}_{2}$, cells pretreated with EPO (either 0.4 or 10 $\mathrm{U} / \mathrm{ml}$ ) exhibited a significant decrease in apoptotic nuclear morphological change evaluated in caspase tissue staining and annexin $\mathrm{V}$ expression in flow 
cytometry. ${ }^{28}$ We also showed in an in vitro study (submitted for publication) that addition of EPO decreased apoptosis induced by $\mathrm{H}_{2} \mathrm{O}_{2}$ in human adipose tissue derived mesenchymal stem cells (MSC), using immunohistochemical caspase staining and annexin $\mathrm{V}$ expression in flow cytometry.

Calvillo et al. ${ }^{23}$ have assessed the potential protective role of EPO in vitro with adult rat cardiomyocytes, and in vivo in a rat model of myocardial infarction with reperfusion. The results showed that EPO markedly prevented the apoptosis of cultured adult rat cardiomyocytes subjected to $28 \mathrm{~h}$ of hypoxia. These observations suggest a potential therapeutic role for recombinant human EPO (rHuEPO $100 \mathrm{ng} / \mathrm{ml}$ ) in the treatment of myocardial ischemia and infarction by preventing apoptosis and attenuating postinfarct deterioration in hemodynamic function. ${ }^{23}$

\section{Myocardial infarction and EPO:}

EPO is a survival factor. EPO can reduce infarct size, cardiomyocyte apoptosis, and diminish ventricular dysfunction in post ischemic injury. EPO treatment during post-MI heart failure improves cardiac function by reducing expression of inflammatory cytokines and oxidative damage, at least in part through activation of the Jak/Stat and PI3K/Akt pathways. ${ }^{32,47}$ Akt-transduction stimulates MSCs to produce paracrine factors that exert a beneficial effect on the infarcted heart post-engraftment. ${ }^{48}$

EPO-R is expressed not only in hematopoietic lineage cells but also in the cardiovascular system. Kagaya et al. ${ }^{49}$ reviewed implications of anemia associated with chronic heart failure by focusing on the EPO-R as a potential candidate of novel therapeutic targets in cardiovascular diseases. rHuEPO and EPO derivatives, have been shown to exert multiple protective actions in animal models of various cardiovascular diseases. However, most clinical trials failed to demonstrate favorable effects of high doses of rHuEPO on myocardial injury induced by ischemia and reperfusion in patients with acute myocardial infarction. ${ }^{49}$

We have shown in our previous study (submitted for publication) that rats with myocardial infarction, induced by coronary artery ligation, represent a smaller infarct area when recombinant human erythropoietin alpha (rHuEPO 5.000 U.kg-1 and 10.000 U.kg-1) is administered. The results were statistically significant when compared with sham group. EPO administration shortly after myocardial infarction in rats reduced the apoptotic activity and the ischemic damage. It also induced new vessel formation.

Calvillo et al. ${ }^{23}$ suggested a potential protective role for EPO in vitro with adult rat cardiomyocytes, and in vivo in a rat model of myocardial infarction with reperfusion. They showed that EPO reduced the amount of apoptotic cells by $30 \%$ in cell culture and normalized haemodynamic function within one week after reperfusion in vivo. ${ }^{23}$

Since adult cardiomyocytes are not able to regenerate, engraftment of stem cells into the adult heart is a new promising and alternative treatment. Mobilization of stem cells and differentiation into cardiomyocytes are known to have protective effects after myocardial infarction. Stem cells are capable of attenuating negative remodeling with subsequent decline in ejection fraction in patients after myocardial infarction. The limitation factor for comprehensive application of the cell therapy for treatment of cardiovascular diseases is the insufficient number of donor cells. Cell transfer studies show promising data with regard to the ability to attenuate myocardial dysfunction upon intracoronary provision of stem cells. EPO mobilizes endothelial progenitor cells from the bone marrow to the periphery and enhances progenitor cell differentiation and proliferation after a short period of administration. Migration of stem cells, resistance to apoptotic cell death, secretion of angiogenic cytokines, proliferation and adhesion are thought to be important for the succesfull cell transfer. There are still significant challenges before stem cell based therapies are advanced for cardiac diseases. Therefore, recently more effective treatment options with the EPO in vitro and in vivo studies for treatment of cardiovascular diseases have been researched. In addition, stem cell therapy protocols and in vitro cardiyomyosit differentiation protocols may be more effective with addition of EPO.

\section{REFERENCES}

1. Jelkmann W. Erythropoietin: structure, control of production, and function. Physiol Rev 1992 72: 449-489, 
2. Eckardt KU, Koury ST, Tan CC, et al. Distribution of erythropoietin producing cells in rat kidneys during hypoxic hypoxia. Kidney Int. 1993 Apr;43(4):815-23.

3. Fisher JW. Erythropoietin: physiology and pharmacology update. Exp Biol Med (Maywood). 2003 Jan;228(1):1-14.

4. Wenger RH. Mammalian oxygen sensing, signalling and gene regulation. J Exp Biol. 2000;203:1253-63. 6.

5. Maxwell PH, Pugh CW, Ratcliffe PJ. Inducible operation of the erythropoietin $3^{\prime}$ enhancer in multiple cell lines: evidence for a widespread oxygen-sensing mechanism. Proc Natl Acad Sci USA. 1993;90:2423-7.

6. Jelkmann W. Molecular biology of erythropoietin. Intern Med. 2004;43:649-59.

7. Jie KE, Verhaar MC, Cramer MJ, et al. Erythropoietin and the cardiorenal syndrome: cellular mechanisms on the cardiorenal connectors. Am J Physiol Renal Physiol. 2006 Nov;291(5):F932-44.

8. Kishore BK, Isaac J, Westenfelder C. Administration of poly-Dglutamic acid induces proliferation of erythropoietin-producing peritubular cells in rat kidney. Am J Physiol Renal Physiol. 2007 Feb;292(2):F749-61.

9. Maxwell AP, Lappin TR, Johnston CF, Bridges JM, McGeown MG. Erythropoietin production in kidney tubular cells. $\mathrm{Br} J$ Haematol. 1990 Apr;74(4):535-9.

10. Ebert BL and Bunn HF. Regulation of the erythropoietin gene. Blood94: 1864-1877, 1999

11. Palis J, Malik J, McGrath KE, Kingsley PD. Primitive erythropoiesis in the mammalian embryo. Int J Dev Biol. 2010;54(6-7):1011-8. Review.

12. Kessinger A and Sharp G. Mobilization of hematopoietic progenitor cells with epoetin alfa. Semin Hematol 2001; 33 (Suppl.10) (Abstr.).

13. Kimura $\mathrm{T}$, Sonoda $\mathrm{Y}$, Iwai $\mathrm{N}$, et al. Proliferation and cell death of embryonic primitive erythrocytes. Exp Hematol. 2000 Jun;28(6):635-41.

14. George J, Goldstein E, Abashidze A, et al. Erythropoietin promotes endothelial progenitor cell proliferative and adhesive properties in a PI 3-kinase-dependent manner. Cardiovasc Res. 2005 Nov 1;68(2):299-306.

15. van der Meer P, Voors AA, Lipsic E, van Gilst WH, van Veldhuisen DJ. Erythropoietin in cardiovascular diseases. Eur Heart J. 2004 Feb;25(4):285-91. Review

16. Erbayraktar $\mathrm{S}$, de Lanerolle $\mathrm{N}$, de Lotbinière $\mathrm{A}$, et al. Carbamylated erythropoietin reduces radiosurgically-induced brain injury. $\mathrm{Mol}$ Med. 2006;12:74-80.

17. Sirén AL and Ehrenreich $H$. Erythropoietin-a novel concept for neuroprotection. Eur Arch Psychiatry Clin Neurosci. 2001;251:17984.

18. Celik M, Gokmen N, Erbayraktar S, et al. Erythropoietin prevents motor neuron apoptosis and neurologic disability in experimental spinal cord ischemic injury. Proc Natl Acad Sci USA. 2002;99:225863.

19. Erbayraktar S, Grasso G, Sfacteria A, et al. Asialoerythropoietin is a nonerythropoietic cytokine with broad neuroprotective activity in vivo. Proc Natl Acad Sci USA. 2003;100:6741-6.

20. Brines M, Grasso G, Fiordaliso F, et al. Erythropoietin mediates tissue protection through an erythropoietin and common betasubunit heteroreceptor. Proc Natl Acad Sci 2004;101:14907-14912
21. Cai Z, Manalo DJ, Wei G, et al. Hearts from rodents exposed to intermittent hypoxia or erythropoietin are protected against ischemia-reperfusion injury. Circulation 2003;108:79-85.

22. Cai $Z$ and Semenza GL. Phosphatidylinositol-3-kinase signaling is required for erythropoietin-mediated acute protection against myocardial ischemia/reperfusion injury. Circulation 2004;109:20502053.

23. Calvillo L, Latini R, Kajstura J, et al. Recombinant human erythropoietin protects the myocardium from ischemia-reperfusion injury and promotes beneficial remodeling. Proc Natl Acad Sci 2003;100:4802-4806.

24. Guneli E, Cavdar Z, Islekel H, et al. Erythropoietin protects the intestine against ischemia/reperfusion injury in rats. Mol Med 2007;13:509-517.

25. Junk AK, Mammis A, Savitz Sl, et al. Erythropoietin administration protects retinal neurons from acute ischemia-reperfusion injury. Proc Natl Acad Sci 2002;99:10659-10664.

26. Lipsic $E$, van der Meer $\mathrm{P}$, Henning $\mathrm{RH}$, et al. Timing of erythropoietin treatment for cardioprotection in ischemia/reperfusion. J Cardiovasc Pharmacol 2004;44:473-479.

27. Moon C, Krawczyk M, Ahn D, et al. Erythropoietin reduces myocardial infarction and left ventricular functional decline after coronary artery ligation in rats. Proc Natl Acad Sci 2003;100:1161211617.

28. Parsa CJ, Matsumoto A, Kim J, et al. A novel protective effect of erythropoietin in the infarcted heart. J Clin Invest 2003;112:9991007.

29. Sharples EJ, Patel N, Brown P, et al. Erythropoietin protects the kidney against the injury and dysfunction caused by ischemiareperfusion. J Am Soc Nephrol 2004;15:2115-2124.

30. Solaroglu A, Dede FS, Okutan E, Bayrak A, Haberal A, Kilinc K. A single dose of erythropoietin attenuates lipid peroxidation in experimental liver ischemia-reperfusion injury in the rat fetus. $J$ Matern Fetal Neonatal Med 2004;16:231-234.

31. Wu H, Ren B, Zhu J, et al. Pretreatment with recombined human erythropoietin attenuates ischemia-reperfusion-induced lung injury in rats. Eur J Cardiothorac Surg 2006;29:902-907.

32. Marzo F, Lavorgna A, Coluzzi G, et al. Erythropoietin in heart and vessels: focus on transcription and signalling pathways. J Thromb Thrombolysis 2008;26:183-187

33. Fiordaliso F, Chimenti S, Staszewsky L, et al. A nonerythropoietic derivative of erythropoietin protects the myocardium from ischemiareperfusion injury. Proc Natl Acad Sci 2005;102:20462051.

34. Ueba $H$, Brines $M$, Yamin $M$, et al. Cardioprotection by a nonerythropoietic, tissue-protective peptide mimicking the 3D structure of erythropoietin.Proc Natl Acad Sci 2010;107:1435714362

35. Marti HH. Erythropoietin and the hypoxic brain. I Exp Biol 2004;207:3233-3242.

36. Juul SE, Yachinis AT, Rojiani AM and Christensen RD. Immunohistochemical Localization of Erythropoietin and Its Receptor in the Developing Human Brain. Pediat. Dev. Pathol. 1999, 2: 148-15

37. Wu H, Lee SH, Gao J, Liu X, Iruela-Arispe ML. Inactivation of erythropoietin leads to defects in cardiac morphogenesis. Development. 1999 Aug;126(16):3597-605 
38. Wang W, Kagaya Y, Asaumi Y, Fukui S, Takeda M, Shimokawa H. Potective effects of recombinant human erythropoietin against pressure overload-induced left ventricular remodeling and premature death in mice. Tohoku J Exp Med. 2011;225(2):131-43.

39. Ribatti $D$, Presta $M$, Vacca $A$, et al.. Human erythropoietin induces a pro-angiogenic phenotype in cultured endohtelial cells and stimulates neovascularization in vitro. Blood 1999, 93, 2627-2636.

40. Wang C, Jiao C, Hanlon HD, Zheng W, Tomanek RJ, Schatteman GC. Mechanical, cellular, and molecular factors interact to modulate circulating endothelial cell progenitors. Am J Physiol Heart Circ Physiol. 2004 May;286(5):H1985-93.

41. Ji RP, Phoon CK, Aristizábal O, McGrath KE, Palis J, Turnbull DH. Onset of cardiac function during early mouse embryogenesis coincides with entry of primitive erythroblasts into the embryo proper. Circ Res. 2003 Feb 7;92(2):133-5.

42. Wald MR, Borda ES, Sterin-Borda L. Mitogenic effect of erythropoietin on neonatal rat cardiomyocytes: signal transduction pathways. J Cell Physiol. 1996 Jun;167(3):461-8.

43. Miller $C B$ and Lazarus HM. Erythropoietin in stem cell transplantation. Bone Marrow ransplantation 2001, 27, 1011-1016

44. Antonitsis P, loannidou-Papagiannaki E, Kaidoglou A, Papakonstantinou C. In vitro cardiomyogenic differentiation of adult human bone marrow mesenchymal stem cells. The role of 5azacytidine. Interact Cardiovasc Thorac Surg. 2007 Oct;6(5):593-7.

45. Leri A, Kajstura J, Anversa P. Cardiac stem cells and mechanisms of myocardial regeneration. Physiol Rev. 2005 Oct;85(4):1373-416. Review

46. Jing D, Parikh A, Canty JM Jr, Tzanakakis ES. Stem Cells for Heart Cell Therapies Tissue Eng Part B Rev. 2008 Dec;14(4):393-406.

47. Li Y, Takemura G, Okada $\mathrm{H}$, et al. Reduction of inflammatory cytokine expression and oxidative damage by erythropoietin in chronic heart failure. Cardiovasc Res. 2006 Sep 1;71(4):684-94.

48. Robey TE, Saiget MK, Reinecke H, Murry CE. Systems approaches to preventing transplanted cell death in cardiac repair. I Mol Cell Cardiol. 2008 Oct;45(4):567-81.

49. Kagaya $Y$, Asaumi $Y$, Wang $W$, et al. Current perspectives on protective roles of erythropoietin in cardiovascular system: erythropoietin receptor as a novel therapeutic target. Tohoku J Exp Med. 2012; 227(2):83-91 